Article (refereed) - postprint

Cameron, lain; Watson, Adam. 2017. Seven Scottish snow patches survive until winter 2016/2017. Weather, 72 (5). 123-125. 10.1002/wea.2980

Copyright @ 2017 Royal Meteorological Society

This version available http://nora.nerc.ac.uk/517248/

NERC has developed NORA to enable users to access research outputs wholly or partially funded by NERC. Copyright and other rights for material on this site are retained by the rights owners. Users should read the terms and conditions of use of this material at http://nora.nerc.ac.uk/policies.html\#access

This document is the author's final manuscript version of the journal article, incorporating any revisions agreed during the peer review process. Some differences between this and the publisher's version remain. You are advised to consult the publisher's version if you wish to cite from this article.

The definitive version is available at http://onlinelibrary.wiley.com

Contact CEH NORA team at noraceh@ceh.ac.uk 


\section{Seven Scottish snow patches survive until winter 2016/17}

Keywords

Snow patches, Scotland

Short title

Scottish snow patches 2016

\section{Iain Cameron ${ }^{1}$ and Adam Watson ${ }^{2}$}

${ }^{1}$ Stirling, Stirlingshire

${ }^{2}$ Emeritus Fellow, Centre for Ecology and Hydrology, Edinburgh

Here we present our twenty first annual report on the survival of Scottish snow patches, following the account for 2015 in Cameron et al. (2016).

\section{Methods}

The compilation of this year's paper was once again aided by the contributions from people - far too many to name individually - using social media; particularly Twitter and Facebook. For brevity, unattributed observations are by authors IC and AW, with information from others being personal communications. Measurements of patches give greatest length, breadth and depth in that order.

\section{Weather in winter through to autumn}

On the Scottish hills, less snow fell than over the previous three winters. It was the thirdwarmest winter for the UK in a series from 1910, behind those of 1989 and 20071. In Scotland, mean daily maximum temperatures were $0.5-1 \mathrm{deg} C$ warmer across the whole country than the 1981-2010 mean. As a result of this, the hills of the Southern Highlands and Uplands, aligned with their lack of relative height, did less well in terms of snow accumulation than those above 3500 feet (1067 metres). (In Scotland, where the climate is dominated by maritime weather systems, the difference between rain and snow falling at 3000 feet (914 metres) can be only a degree-or-so.) On higher hills farther north, though, it was cold enough for build-ups of deep snow on favoured north-east facing aspects above 3500 feet.

Though April was cooler than normal - culminating in an extraordinary late fall to low levels in Fife and Stirlingshire - May and June were both milder, resulting in snow melting quickly at lower altitudes. Fresh snow was observed on only one day during June-September (at Ben Nevis on 1 July, D. Buckett), the lowest total since 2006, when none was observed (Watson et al 2007).

\section{Patches in late spring, summer and autumn 2016}

April-July

\section{Southern Scotland}

During a visit to Cramalt Craig and Broad Law in the Borders on 22 April, IC found many big wreaths, the largest of which, on the latter, being in excess of $150 \mathrm{~m}$ long. On the former he found evidence of a significant avalanche, from which the two metre high crown wall was still visible. On 28 April a remarkable 12-hour snow-event occurred in eastern and central Scotland, with over $250 \mathrm{~mm}$ recorded on the Lomond Hills of Fife (B. Dolphin), and massive drifts up on the Ochils hills near Stirling (see Fig. 1). Though this unconsolidated snow melted rapidly in subsequent days, a patch endured until 9 May at Ben Cleuch in the Ochils (M. Johnson).

At Corserine in the Galloway Highlands, IC saw on 24 April, in astonishingly clear light from Ben Ledi, some 76 miles away, a large patch on its north-east flank. P. Woolverton observed the 
same snow on 11 May at closer quarters, and we estimate that it lasted until a few days later. What we suspect to be the last snow in the Southern Uplands, a wreath on Talla East Side in the Borders, melted shortly after 22 May.

\section{West and Central Highlands}

A small patch endured until 1 June on Mull's Ben More, which is unusually late for this hill (J. Westland). Across Loch Linnhe, on Ben Cruachan, a few small patches were seen on 27 June, but these would have gone before the end of the month. On the hills around Glen Coe, snow melted earlier than in the previous few years. Meall a' Bhuiridh's last remnants disappeared on 28 July (A. Meldrum), with Bidean nam Bian's going approximately on the same date, having been seen to be 'small' on the 23rd.

As usual, the last patch to disappear on the Ben Lawers range was on the north shoulder of An Stuc. IC visited here on 8 July and saw it to be approximately $20 \times 10 \times 1$ metres. We estimate that this would have vanished by 16 July. The fragments of the well-known Cuidhe Chrom ('curved wreath') of Ben More at Crianlarich were spotted in good light by A. Meldrum on 14 July, and he estimated a final melt date of 17 July. At Carn na Caim near Dalwhinnie snow persisted to 16 July, far sooner than in the previous years, indicating a lack of easterly storms over winter.

At Coire nan Con of Ben Wyvis, in the North-West Highlands, C. Anton saw a large patch of $50 \times 10 \times 2$ metres on 23 July, but this would have melted in early August

\section{East Highlands}

The 41st annual survey of the north-east Highlands was undertaken on 1 July by AW and IC, with help from Glenshee ski centre manager Graham McCabe, and Derek Pyper. All four went to Meall Odhar, an excellent viewpoint. There, the weather quickly turned from sunshine to a gale-driven blast of rain and sleet. AW had to be careful to prevent his saturated hand-written notes from being blown away. Mist enshrouded all higher hills, but, one by one, each appeared briefly, enabling AW to take notes and IC photographs of all the hills. Later, down in Deeside, AW and DP observed Lochnagar and several other hills not visible from Meall Odhar. Meanwhile IC completed the survey by taking photographs from Strath Don, Tomintoul and Glen More, before climbing to Ben Macdui plateau in improving weather.

To conclude, Lochnagar, hills east of Glen Tilt, and the eastern Cairngorms held far less snow than usual. In almost every year, the longest wreath in Scotland at the start of July is in the Snowy Corrie of Ben Macdui, often more than 1km long. In 2016, however, it was easily surpassed by a deep and long (more than $400 \mathrm{~m}$ ) patch in Garbh Uisge Beag further north (see Fig. 2). Garbh Choire Mor on Braeriach held large wreaths, the biggest one darkened by boulders and earth that had come down the snow from the cliffs above. Far less snow than usual lay in Ciste Mhearad of Cairn Gorm. Melting had been increased there by large hollows dug by parties practising snow-holing for winter survival, and such hollows also occurred on the snow of Garbh Uisge Beag.

\section{August and September}

\section{All-Scotland survey in late August}

The ninth all-Scotland survey since 2008 took place on 20 and 21 August. A total of 82 patches was observed across the country. Their location and numbers were as follows: Ben Nevis, 23; Aònach Mòr, 10; Aònach Beag, 8; Geal-Charn (Ben Alder), 2; Ben Macdui/Cairn Gorm, 19; Beinn a' Bhuird, 1; Braeriach, 9; Creag Meagaidh, 7; An Riabhachan, 2; Beinn Dearg (Ullapool), 1. In the eight previous years (2008-2015) the number of patches had been 77, 35, $34,36,72,81,281$ and 678 . 


\section{North-West Highlands}

On the high hills around Loch Mullardoch, C. Anton saw most of the last snows north of the Great Glen, and noted their disappearance. At Tom a' Choinich on 14 August he saw a tiny patch and estimated its demise to be less than 24 hours away. At nearby An Riabhachan he observed an additional two patches on 21 August, both of which would have succumbed shortly thereafter. On Beinn Dearg near Ullapool, A. Rowan saw a patch approximately 12 metres wide on 21 August, with final melting likely to be before the end of the month. Were it not for the fact that this patch was firn from the previous year, we judge it would have melted sooner than it did.

\section{West and Central Highlands}

Large patches persisted across the Ben Nevis range of hills on 20 August. IC, B. Fyffe, M. Atkinson and B. Boyes visited the range on this date and saw one 147 metres long at Observatory Gully, with upwards of eight metres depth. At the adjacent Point 5 Gully a deep patch was noted, complete with impressive sculptures and ablation hollows (see Fig. 3). During a climbing trip on 15 September A. Halewood saw both these patches, with the latter looking small.

IC visited Aònach Mòr's Coire an Lochain on 18 September and observed a couple of tiny remnants at the protalus rampart ridge. These would have melted a day or so later. There were a couple of larger patches at the so-called Piranha location (named after the rock-climb above it) 100 metres to the north, but these would have succumbed by 25 September.

\section{East Highlands}

The noted long-lying snow on Beinn Mheadhoin's north flank disappeared on the unusually early date of 1 August (N. Bullivant), in contrast to 2014 when it persisted till 11 November.

Snow-patch enthusiast S. Grant as usual monitored the north and west side of the Cairngorms from his house in Inverdruie. He informs us that the last snow had gone at Cairn Gorm's Cuithe Chròm on 7 August and Coire an Lochain on 23 August, and at Braeriach's Coire an Lochain on 26 August.

At Lochnagar above Deeside, G. Jones confirmed that no snow was left on that massif by 14 August, another unusually early date. IC went to Creag Meagaidh on 6 August with B. Dolphin and saw a massive remnant in Coire Ardair's Easy Gully, and a small patch at Raeburn's Gully, the latter being almost three years old, having survived the previous two winters. The Easy Gully patch was seen again on 21 August by E. Boyle, much reduced but still large, and would have lasted until at least the second week in September.

On the Cairn Gorm/Ben Macdui plateau, Coire Domhain's last snow disappeared on 6 September. At Garbh Uisge Beag, a patch of 53 x 14 x 2 metres was seen by IC on 3 September, and would have persisted until the middle of that month. Ciste Mhearad's last wreath vanished on 11 September (N. Bullivant).

The UK's snowiest place, Garbh Choire Mòr of Braeriach, was visited on 13 August by IC. The two most durable patches there, Sphinx and Pinnacles, were still conjoined. In a subsequent visit on 10 September it was seen that they had split, measuring $20 \times 15 \times 2.5$ metres and $38 \times 15$ x 2.5 metres respectively.

\section{October and November}

\section{West Highlands}

All snow in the West Highlands in October and November was confined to just Ben Nevis and its neighbour, Aònach Beag. At the former's Point 5 Gully, a 'tiny sliver' was seen by G. Hodgson on 8 October, and would have vanished that day or the next. Higher up Observatory Gully on 14 October, IC saw a large patch enduring, with significant depth. Its irregular shape 
and poor weather made measurement difficult, but we estimate it to have been over 50 metres long. This patch was seen again on 24 October by A. Halewood, and had split into six pieces. He confirmed our suspicion that the fresh snow which fell on 17 October did not reach the older remnants. Heavy snow with drifting came to this location on 2 November, and buried the four extant patches. This snow proved to be lasting.*

When visited on 5 November by IC and B. Fyffe, the large patch ( $55 \times 27$ x 4 metres) below Aònach Beag's north-east face was covered in new snow that had fallen on the previous day. The old snow dwarfed all other patches in Scotland in both length and volume. In addition to its size, the upper levels of the snow were very hard firn, as might be expected given its three-year age. Cool temperatures and subsequent heavy snow would have buried this patch in the coming days, and although there was a period of mild weather thereafter, we do not think the snow which fell on 4 November would have resurfaced, and estimate this as the date when lasting snow arrived.

\section{East Highlands}

On a visit to Braeriach's Garbh Choire Mòr on 1 October, IC and B. Boyes measured the Sphinx and Pinnacles patches at $14 \times 12 \times 3$ metres and $28 \times 7 \times 1$ metres respectively. No other old snow persisted anywhere else in the Cairngorms during October and November. G. Hodgson saw these patches reduced in size when he observed them on 6 October from Ben Macdui. The last confirmed sighting of them was just over a week before heavy snow fell on 1 November. Drifting was in evidence at Cairn Gorm and Braeriach on this date, and we judge this snow would have buried the old. As with Ben Nevis and Aònach Beag, subsequent mild weather would not have stripped this new snow, and we consider it to have been lasting.

\section{Conclusions}

Seven patches survived until the following winter's snows. Four were on Ben Nevis, one on Aònach Beag, and two on Braeriach. Lasting snow came to the Braeriach patches on 1 November, Ben Nevis on 2 November, and Aònach Beag on 4 November.

\section{Acknowledgements}

Special thanks are due to Mark Atkinson, Alex Barbour, Helen Rennie, Eddie Boyle, Colin Miller and Blair Fyffe for repeated visits. We also thank Calum Anton, Ben Boyes, David Buckett, Nic Bullivant, George Charles, Brian Findlay, Andrew John Finnimore, Seumas Grant, Alan Halewood, Gary Hodgson, Mark Johnson, Glyn Jones, Graham McCabe, Ruari Macdonald, Alan Mackay, Mick McKie, Andy Meldrum, George Paton, Derek Pyper, James Westland and Peter Woolverton.

* - Lasting snow is that which falls on an old snow patch, and which subsequently fails to melt, even if it does not bury it at that time.

\section{References}

${ }^{1}$ http://www.metoffice.gov.uk/climate/uk/summaries/2016/winter

Watson, A, Duncan, D, Pottie J. 2007. No Scottish snow survives until winter 2006/07. Weather 62: 71-73

Cameron, I, Watson, A, Duncan, D. 2016. Seventy four snow patches survive until winter 2015/16. Weather 71: 228-230.

Correspondence to: Iain Cameron, iainjamescameron@hotmail.com

DrAdam Watson, adamwatson@uwclub.net

(C) Royal Meteorological Society, 2017 
Figure 1. The wreath known locally as Lady Alva's Web, formed after unusually heavy snow fell on 28-29 April. Sunset on 29 April. (C) Iain Cameron)

Figure 2. Evening light partially bathes the summit cone of Ben Macdui on 1 July, with the 400 metre long wreath of Garbh Uisge Beag stretching across the middle of the picture. (C) Iain Cameron)

Figure 3. Ben Boyes and Blair Fyffe stand underneath an impressive snow arch at Point 5 Gully, Ben Nevis on 20 August. The tall rock wall in the background is Tower Ridge. (C) Iain Cameron) 
Figure 1. The wreath known locally as Lady Alva's Web, formed after unusually heavy snow fell on 28-29 April. Sunset on 29 April. (@ Iain Cameron)

$772 \times 514 \mathrm{~mm}(180 \times 180 \mathrm{DPI})$ 
Figure 2. Evening light partially bathes the summit cone of Ben Macdui on 1 July, with the 400 metre long wreath of Garbh Uisge Beag stretching across the middle of the picture. (@ Iain Cameron)

$306 \times 204 \mathrm{~mm}(180 \times 180 \mathrm{DPI})$ 
Figure 3. Ben Boyes and Blair Fyffe stand underneath an impressive snow arch at Point 5 Gully, Ben Nevis on 20 August. The tall rock wall in the background is Tower Ridge. (@ Iain Cameron)

$306 \times 204 \mathrm{~mm}(180 \times 180$ DPI $)$ 


\section{Graphical table of contents}

\begin{tabular}{|l|l|}
\hline Article title & Seven Scottish snow patches survive until winter 2016/17 \\
\hline Authors' names & Cameron, lain. Watson, Adam \\
\hline $\begin{array}{l}\text { Summary of key } \\
\text { findings }\end{array}$ & $\begin{array}{l}\text { Seven patches of snow survived on the hills of Scotland from the winter of } \\
2015 / 16 \text { to the winter of 2016/17 }\end{array}$ \\
\hline Figure & \\
\hline
\end{tabular}

